\title{
Abbreviations and Conventions
}

\section{Source Abbreviations}

BXDA Baxian dang'an (Ba County archives). Selections from the archives held at the Sichuan Provincial Bureau of Archives.

$B X D A H B$ Baxian dang'an huibian (Selections from the Ba County archives). Beijing: Dang'an chubanshe, I99I.

BXNJ "Baxian nongcunjingji zhiyanjiu" (The Peasant Economy of Ba Countyl, in Minguo ershi niandai zhongguodalu tudi wenti ziliao (Materials and the Land Problem in Mainland China in the Republican Era of the I920s), vol. 54, Wang Guodong ed. Reprint, Zheng Xiao ed., Taipei: Chengwei chubenshe, I978.

BXZ/MG Baxian zhi minguo (Ba County Gazetteer, Republican period, I939). Reprint, Taipei: Xuesheng shuju, 1967.

BXZ/TZ Baxian zhi tongzhi (Ba County Gazetteer, Tongzhi period, I 8671 .

BXZXZ Baxian zhi xuanzhu (Selections from the Ba County Gazetteer|. Chongqing: Chongqing chubanshe, I989.

CD Sichuan daxue dang'an (Sichuan University archives). Selections from Ba County archival transcriptions held at Sichuan University.

CFZL Liubu chufenzeli (Disciplinary Regulations of the Six Boards), Guangxu Period I8 (I882). Reprint, Shen Yunlong ed., Taipei: Wenhai chubanshe, I960.

DLCY Duli cunyi (Doubts Remaining After Perusing the Substatutes), Xue Yunsheng, ed., I905. Taiwan reissue, Huang Tsingchia, ed., 5 vols., Taipei: Chinese Materials and Research Aids Service Center, I970. 
HCJSWB Huangchao jingshi wenbian (Collected Qing Memorials on Statecraft). Taipei: Guofeng chubanshe, I963.

HCJSWXB Huangchao jingshi wenxubian (Supplement to the Collected Qing Memorials on Statecraft).

MLS Muling shu (Selected writings of Local Officials), ed. I 868.

QCWXTK Qingchao wenxian tongkao (A Compendium of Qing Dynasty Writings). Reprint, Wu Yanwu ed., Shanghai: Shangwu yinshuguan, 1936.

QHDSL Qing huidian shili (Collected Statutes and Substatutes of the Qingl, ed. I899. Reprint, Beijing: Zhonghua shuju, I99I.

SCCZ Qingdai Sichuan Caizheng shiliao (Historical material on Financial Administration in Sichuan during the Qing). Xun Zijian, ed. Reprint, Chengdu: Sichuansheng shehuikexueyuan chubanshe, I984.

SCZC Sichuan tongshi zhangcheng (Regulations of Sichuan Province). Shun Yunlong, ed. Taipei: Wenhai chubanshe, 1977.

SCDASL Sichuan dang'an shiliao (Historical material from the Sichuan archives).

SKSS Sichuan kuanmu shuomingshu (Introduction to the Taxes of Sichuan), reprint in Jindaishi ziliao, no. 64, Zhongguo shehui kexueyuan jindaishi yanjiusuo, 1987.

XZZZXS Xingzheng zizhi xinshu (Collected Materials on Administration). $\mathrm{I} 667$.

YLYY Yongli yongyan (Plain Talk on Administrative Matters). Liu Heng. I 827.

ZZCG Zhizhe chenggui (Administrative Regulations of Zhejiang Province). I 837.

All citations from the Ba County archives in this study will follow the cataloging conventions used by the Sichuan Provincial Archives (Sichuansheng dang'anguan). Numbers following the designation BXDA refer to category, catalogue, and juan. For those files containing multiple and discrete case records, the document number within the file will be appended to the basic citation.

Transcriptions of Ba County archival material housed at Sichuan University in Chengdu will be identified as CD. This will then be followed by the conventions used by the university to classify these transcriptions: a name denoting a category of files, another name for the subcategory, and a number indicating the specific file (see glossary for characters used in category and subcategory titles). Where relevant this will be followed by the reign period and year of the file. 
Date Abbreviations

Abbreviations for reign names are as follows:

$\begin{array}{llll}\text { YZ } & \text { Yongzheng } & \text { XF } & \text { Xianfeng } \\ \text { QL } & \text { Qianlong } & \text { TZ } & \text { Tongzhi } \\ \text { JQ } & \text { Jiaqing } & \text { GX } & \text { Guangxu } \\ \text { DG } & \text { Daoguang } & \text { XT } & \text { Xuantong }\end{array}$

Weights and Measures

The following are the standard English equivalents for Chinese weights and measures given throughout:

li $=0.3$ I mile

I $\mathrm{mu}=0.16$ acre

I shi $=$ approximately 176 pounds

I tael (liang) $=$ approximately one ounce of silver

I qian $=$ o. Io tael

I fen $=0.0$ i tael

I wen $=$ single copper coin (cash). Depending on the exchange rate, in nineteenth-century Sichuan I silver tael was worth $800-1,800$ copper wen.

\section{Translations}

All translations are my own unless otherwise noted. 

Virtuous laws and fine intentions are all ruined by treasonous clerks and verminous runners.

-Circuit Intendant Du Renshou, ca. I 880 


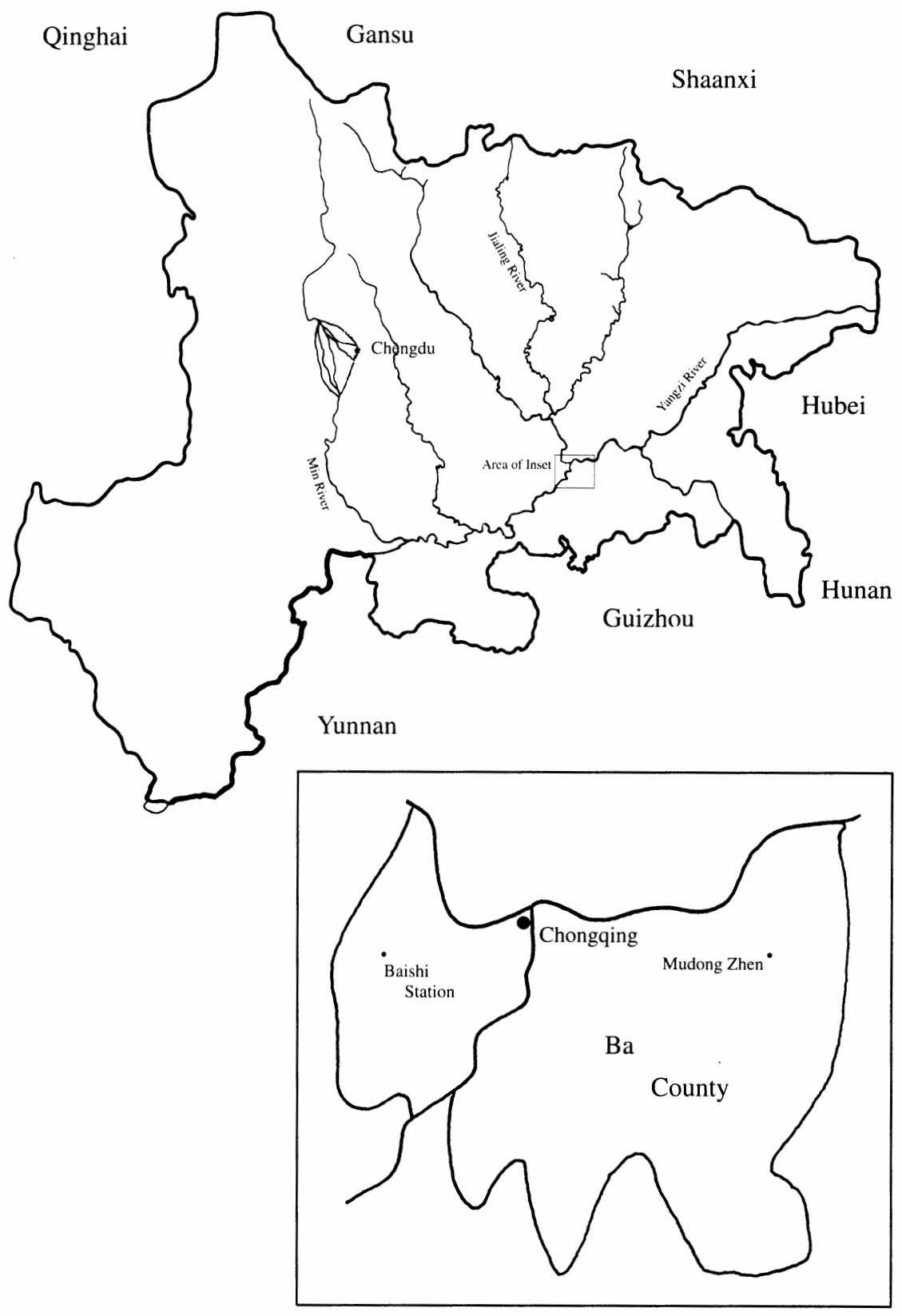

Sichuan Province During the late Qing Dynasty, with Ba County Highlighted. 